\title{
PHYTOCHEMICAL AND ANTIOXIDANT SCREENING OF ZINGIBER OFFICINALE, PIPER NIGRUM, RUTAG RAVEOLANES AND CARUM CARVI AND THEIR EFFECT ON GASTROINTESTINAL TRACT ACTIVITY
}

\author{
Muhammad Qasim Barkat*, Hafiz Khalid Mahmood \\ Institute of Pharmacy, Physiology and Pharmacology, University of Agriculture, Faisalabad, Pakistan \\ *Corresponding Author's E-mail: qasimbarkat07@gmail.com
}

This is an open access article distributed under the Creative Commons Attribution License, which permits unrestricted use, distribution, and reproduction in any medium, provided the original work is properly cited.

\section{ARTICLE DETAILS}

Article History:

Received 12 November 2017 Accepted 12 December 2017 Available online 1 January 2018

\section{ABSTRACT}

Herbal plants are used widely for the treatment of stomach disorders as peptic and duodenal ulcer, dyspepsia, gastritis and other ailments. There are many causes of ulcer but $80 \%$ of the ulcer caused by H-Pylori in the GIT problems. Uses of NSAID are the main cause of GIT problems in human health. In the developed countries, mostly peoples used herbal plants regularly for the stomach problems. These herbal plants contain different photochemical constituents as alkaloids, flavonoids, phenols, tannins and saponins. They not only have bioactive compounds but also have antioxidants properties that strengthen the stomach health and prevent from oxidative stress and other scavenging properties. The use of herbal plants is economical and safe for these types of diseases. The herbal plants treatment has been used for stomach disorders without chances of reoccurrence.

\section{KEYWORDS}

Stomach disorders, duodenal ulcer, H-Pylori, NSAID, photochemical.

\section{INTRODUCTION}

The UNESCO observed that the medicinal plants are used in the developed countries for the good health maintenance whereas the peoples of less developed countries (3.3 billion) used the medicinal plants regularly. According to a study, the medicinal plants have been used for different diseases for thousands of years as they contain rich source of ingredients which are used for different purposes and the active components has biological properties being used all over the world [1]. The medicinal plants play a vital role to provide normal health to people. These herbal medicinal plants contain different bioactive constituents that act on human body. The chief constituents having medicinal properties are flavonoids, phenols, alkaloids and tannins. Based on research, they are used for different purposes as spices, food and for nursing and pregnant mothers [2].

Reactive oxygen species are reactive molecules because of presence of unpaired electron and are formed from the living organism by product of cellular normal metabolism. At low concentration, it causes the physiological normal cell response whereas modification of cell, oxidative stress, lipids, proteins, and DNA are produced at high concentrations. Based on research, the oxidative stress develops about 100 disorders, but the antioxidants prevent and keep in balance of harmful reactions $[3,4]$. According to research, ROS is the combination of oxidants and antioxidants. Oxidants are produced from endogenous (superoxide anion, hydrogen peroxide and hydroxyl radical) and exogenous species (ozone, cigarette smoke, hypoxia and heavy metals) whereas antioxidants are produced from enzymatic (catalase, superoxide dismutase, glutathione peroxidase and glutathione transferase) and nonenzymatic antioxidants (vitamin A, C and E) [3].

There are different types of gastric disorders which may perhaps disturb human health. Peptic and duodenal ulcer, dyspepsia and gastritis are the gastric disorders. There are many causes of ulcer but eighty (80\%) of the ulcer caused by H-Pylori in the GIT problems. Peptic ulcer is the main causative factor of gastric problems in the GIT. NSAIDS, alcohol, stress, starvation and malnutrition are the causes of ulcer. Omeprazole, ranitidine and metronidazole are used as treatment protocols for the gastric and ulcer problems, but this treatment is expensive, unsafe and chances of reoccurrence are more whereas the herbal plant treatment is the better choice for the gastric problems that is safe, economical and permanently eradicate such diseases [5]. In this review paper, there are four different plants zingiber officinale, piper nigrum, ruta graveolanes and carum carvi that has vital activity in opposition to GIT problems.

\section{REVIEW}

Zingiber officinale holds family of zingiberaceae [6]. Based on research, ginger have been found in Africa, Asia, China and India [7]. It holds twelve hundred (1200) species and fifty-three (53) genera. The common names of Zingiber officinale are adrak, ginger, ada and sonth. It contains 1-4\% volatile oils approximately in the dried rhizome. Gingerol and zingiberene are essential oils that present in ginger and recognized by GC, it has tenacious, warm balsamic and spicy odor. A study shows that the active constituents of zingiberene and bisbolene responsible for the odor and taste of adrak whereas gingerols and shogaols for pungent smell [8]. According to a research, it generally contains monoterpenoids volatile oils such as cineol, shogaols, terpineol, beta phellandrene, curcumene, camphene, gerniol, gingerol and sesquiterpenoids as zingiberol, alpha zingiberene $(30-70 \%)$, beta bisbabolene $(10-15 \%)$ and beta sesquiphellandrene [6]. It holds antioxidants as flavonoids, alkaloids, rutin terpenoids, beta carotene, glycoside and flavones [9]. According to research, it contains vitamins as folic acid, alpha tocopherols, ascorbic acid and antioxidants like as flavonoids, carotenoids, cinnamic acid, benzoic acids, tocotrienols and tocopherols but ascorbic acid, beta carotene and alpha tocopherols are used as mainly antioxidants [10]. Based on a study, ginger has been used in stomach ailments like vomiting, diarrhea and heartburn [11]. It can be used for stomach ulcer due to presence of phenolic contents $(1-4 \%)$ that inhibits the proton pump (H/K ATPase) while it also stops the growth of $\mathrm{H}$ - Pylori (Helicobacter pylori) infection which decrease the production of oxidative stress and to remove ulcer. It acts as spasmolytic, carminative and antiemetic as like as metoclopramide in the gastrointestinal (GIT) problems, this activity absorbs the toxin that 
decrease the motility which stop the nausea [12]. Based on a research, ginger has been used for the treatment of diarrhea, bloating, vomiting and also to keep the intestinal muscles in toned. Ethanolic extract of Zingiber officinale has activity of anthelmintic in opposition to Ascaris lumbricoides (Human) [8]. Ginger can be used for the treatment of motion sickness, vomiting, nausea (in pregnancy) and digestion [13]

According to a research, helicobacter pylori infection has been inhibited by ginger for the reason that ammonia secretes by H-Pylori, which is the main causative factor for the ulcer; it may also neutralize the surplus hydrochloric acid (HCL) in the stomach that cause the ulcer problems [14]. The enzyme of COX-1 and COX-2 has been inhibited strongly by ginger. NSAID (Indomethacine) induced ulcer has been treated by ginger whereas it has greater anti-ulcer activity in opposition to NSAID induced ulcer than ranitidine which used as safely for ulcer than other treatment protocols
[15]. Adrak (Zingiber officinale) has anti-ulcer activity due to presence of phenolic acid that inhibits the proton pump $\left(\mathrm{H}^{+} / \mathrm{K}^{+}\right.$ATPase $)$and this pump facilitates the HCL production. It also has gastro protective, digestive and carminative activity [16]. The Zingiber officinale has been analyzed as phytochemically qualitative and quantitative whereas in vivo and in vitro antioxidant activity in the table 2.1, 2.2, 2.3 and 2.4 respectively.According to a study, Piper nigrum belongs to the piperaceae family [17]. It's found in west Bengal lower hills and locates in the region of Indo-Malayo [18]. The common names are pepper corn or black pepper [19]. It contains main metabolites beta bisbolene, trans-beta-caryophyllene, cis oleic acid piperyline, piperene and other sesquiterpenes [17]. The Vitamins present in black pepper are K, A, E, C, choline, pyridoxine, riboflavin, thiamin, folic acid and niacin whereas the major are $\mathrm{K}, \mathrm{E}$ and $\mathrm{A}$. The chief minerals present in Piper nigrum are calcium, copper, iron, phosphorus, magnesium, manganese and zinc.

Table 1: Qualitative analysis of plant extract.

\begin{tabular}{|c|c|c|c|c|}
\hline \multirow{3}{*}{$\begin{array}{l}\text { Test } \\
\text { Alkaloids }\end{array}$} & \multicolumn{3}{|c|}{ Plant extract } & \multirow{3}{*}{$\begin{array}{l}\begin{array}{l}\text { Ruta graveolens } \\
\text { Aqueous }\end{array} \\
+++\mathrm{ve}\end{array}$} \\
\hline & \multirow{2}{*}{$\begin{array}{l}\begin{array}{l}\text { Zingiber officinale } \\
\text { Ethanolic }\end{array} \\
+\mathrm{ve}\end{array}$} & \multicolumn{2}{|c|}{$\begin{array}{l}\text { Piper nigrum } \\
\text { Ethanolic Aqueous }\end{array}$} & \\
\hline & & $+\mathrm{ve}$ & + ve & \\
\hline Amino acids & $+v e$ & -ve & -ve & -ve \\
\hline Carbohydrates & -ve & -ve & -ve & $++v e$ \\
\hline Cardiac glycosides & -ve & -ve & -ve & -ve \\
\hline Flavonoids & -ve & $+\mathrm{ve}$ & + ve & $+++\mathrm{ve}$ \\
\hline Glycosides & +ve & -ve & -ve & $++\mathrm{ve}$ \\
\hline Hydrolysable tannins & -ve & -ve & -ve & -ve \\
\hline Oils / Fats & -ve & -ve & -ve & -ve \\
\hline Phenols & -ve & + tve & $+\mathrm{ve}$ & -ve \\
\hline Protein & +ve & -ve & -ve & -ve \\
\hline Reducing sugar & +ve & -ve & -ve & -ve \\
\hline Resins & $+v e$ & -ve & -ve & $++\mathrm{ve}$ \\
\hline Saponin & -ve & -ve & -ve & $++\mathrm{ve}$ \\
\hline Steroids & -ve & -ve & -ve & -ve \\
\hline Sterols terpenes & $+v e$ & + ve & -ve & $++v e$ \\
\hline Tannins & -ve & -ve & -ve & $++v e$ \\
\hline Terpenoids & -ve & -ve & -ve & -ve \\
\hline Volatile oils & -ve & -ve & -ve & -ve \\
\hline
\end{tabular}

- +Ve: Indicate positive test

- $\quad$-Ve: Indicate negative test

Table 2: Quantitative analysis of plant extract.

\begin{tabular}{|c|c|c|c|c|}
\hline \multirow[t]{2}{*}{ Test } & \multicolumn{4}{|c|}{ Plant extract } \\
\hline & $\begin{array}{l}\text { Zingiber officinale } \\
\text { Methonolic }\end{array}$ & $\begin{array}{l}\text { Piper nigrum } \\
\text { Aqueous, Dichloromethane, } \\
\text { Ethanol, Hexane }\end{array}$ & $\begin{array}{l}\text { Ruta graveolens } \\
\text { Methanolic }\end{array}$ & $\begin{array}{l}\text { Carum carvi } \\
\text { Methanolic }\end{array}$ \\
\hline Alkaloids (\%) & Not analysed & $7.8 \pm 0.32$ & Not analysed & Not analysed \\
\hline Flavonoids (mg/g) & \begin{tabular}{lc}
\multicolumn{2}{l}{ Halia Bentong } \\
$\quad$ Leaves & $5.54 \pm 1.83$ \\
Stem & $1.36 \pm 0.85$ \\
Rhizome & $3.6 \pm 0.45$ \\
Halia Bara & \\
$\quad$ Leaves & $7.05 \pm 7.4$ \\
Stem & $1.77 \pm 0.75$ \\
Rhizome & $4.21 \pm 0.98$ \\
\end{tabular} & $9.7 \pm 0.23$ & Not analysed & Not analysed \\
\hline Phenol (mg/g) & \begin{tabular}{lc}
\multicolumn{3}{l}{ Halia Bentong } \\
Leaves & $33 \pm 1.13$ \\
Stem & $7.8 \pm 0.65$ \\
Rhizome & $10.22 \pm 0.87$ \\
Halia Bara \\
Leaves & $39.1 \pm 9.2$ \\
Stem & $8.5 \pm 0.81$ \\
Rhizome & $13.5 \pm 2.26$
\end{tabular} & Not analysed & $4.3 \pm 0.4$ & $0.07 \pm 0.00$ \\
\hline Saponin(\%) & Not analysed & $0.65 \pm 0.09$ & Not analysed & Not analysed \\
\hline Tannins (\%) & Not analysed & $33 \pm 0.29$ & Not analysed & Not analysed \\
\hline
\end{tabular}


Table 3: In vivo anti-oxidant activity of plants.

\begin{tabular}{|l|l|l|}
\hline \multirow{2}{*}{ Parameter } & Investigation in Serum and Plasma samples \\
\cline { 2 - 3 } & Zingiber officinale & Piper nigrum \\
\hline Super Oxide Dismutase (U/gm) & $620 \pm 22.56$ & $17.20 \pm 3.06$ \\
\hline $\begin{array}{l}\text { Catalase } \\
(\mathrm{U} / \mathrm{gm})\end{array}$ & $2.51 \pm 0.49$ & $0.161 \pm 0.017$ \\
\hline Blood Total Glutathione $(\mu \mathrm{mol} / \mathrm{ml})$ & $218.30 \pm 46.2$ & $0.154 \pm 0.014$ \\
\hline $\begin{array}{l}\text { Serum Glutathione Reductase } \\
(\mathrm{U} / \mathrm{ml})\end{array}$ & $1.20 \pm 0.26$ & Not analysed \\
\hline $\begin{array}{l}\text { Serum Glutathione -S- Transferase } \\
\text { (n.mol/mg) }\end{array}$ & $0.98 \pm 0.37$ & Not analysed \\
\hline $\begin{array}{l}\text { Serum Glutathione Peroxidase } \\
(\mathrm{U} / \mathrm{gm})\end{array}$ & $5.94 \pm 0.45$ & Not analysed \\
\hline $\begin{array}{l}\text { Thiobarbituric Acid Reactive } \\
\text { Substance } \\
\text { (n.mol/ml) }\end{array}$ & $3.11 \pm 0.77$ & Not analysed \\
\hline
\end{tabular}

U: Enzyme activity or units $(\mathrm{U})$ is the amount of enzyme that converts one micro mole of substrate per minute, $1 \mathrm{U}=1 / 60$ micro katal $=16.67$ nano katal.

Table 4: In vitro anti-oxidant activity of plants.

\begin{tabular}{|c|c|c|c|}
\hline \multirow[t]{2}{*}{ Test } & \multicolumn{3}{|l|}{ Methanolic plant extract } \\
\hline & Zingiber officinale & Piper nigrum & Carum carvi \\
\hline $\begin{array}{l}\text { DPPH } \\
\text { picrylhydrazyl) }\end{array}$ & \begin{tabular}{lc}
\multicolumn{3}{l}{ Halia Bentong } & $(\mu \mathrm{g} / \mathrm{ml})$ \\
Leaves & $51.12 \pm 1.65$ \\
Stem & $32.85 \pm 0.57$ \\
Rhizome & $51.41 \pm 0.51$ \\
Halia Bara $\quad(\mu \mathrm{g} / \mathrm{ml})$ \\
Leaves & $56.36 \pm 0.97$ \\
Stem & $31.45 \pm 1.49$ \\
Rhizome & $58.22 \pm 1.19$ \\
\end{tabular} & $3.56 \pm 1.32 \quad(\mu \mathrm{g} / \mathrm{ml})$ & $153 \pm 2.34(\mu \mathrm{mol} / \mathrm{g})$ \\
\hline $\begin{array}{l}\text { FRAP (Ferric reducing/antioxidant } \\
\text { power) }\end{array}$ & $\begin{array}{lrl}\text { Halia Bentong } & (\mu \mathrm{mol} / \mathrm{g}) \\
\text { Leaves } & 537.94 & \pm 37.3 \\
\text { Stem } & 376.94 & \pm 50.97 \\
\text { Rhizome } & 680.68 & \pm 18.38 \\
\text { Halia Bara } \quad(\mu \mathrm{mol} / \mathrm{g}) & \\
\text { Leaves } & 579.6 \pm & \pm 61.94 \\
\text { Stem } & 368.27 & \pm 23.43 \\
\text { Rhizome } & 767.2 \pm & \pm 1.53 \\
\end{array}$ & Not analysed & $75.6 \pm 0.4 \quad(\mu \mathrm{mol} / \mathrm{g})$ \\
\hline $\begin{array}{l}\text { ABTS } \quad(2,2 \text { '-azino-bis } \\
\text { ethylbenzothiazoline-6-sulphonic } \\
\text { acid) }\end{array}$ & Not analysed & Not analysed & $13.1 \pm 0.05(\mu \mathrm{mol} / \mathrm{g})$ \\
\hline NO (Nitrogen oxide radical) & Not analysed & $5.23 \pm 3.28 \quad(\mu \mathrm{g} / \mathrm{ml})$ & Not analysed \\
\hline $\mathbf{O}^{-}{ }_{2}$ (Superoxide anion radical) & Not analysed & $8.95 \pm 4.28(\mu \mathrm{g} / \mathrm{ml})$ & Not analysed \\
\hline •OH (Hydroxyl radical) & Not analysed & $17.27 \pm 4.12(\mu \mathrm{g} / \mathrm{ml})$ & Not analysed \\
\hline
\end{tabular}

Based on research, Piperene is the main constituent which responsible for pungent smell of pepper corn [21] It's used as carminative and appetite stimulant [19]. The preferably use of pepper corn in cholera, flatulence, indigestion and anorexia. It may also increase the secretion of pepsin and potassium loss in parietal cells, in addition to this act as anti-ulcer [22]. According to a study, it has activity against colonic toxin, chronic indigestion, vertigo and diarrhea [23]. It acts as appetizer as a result of the liver function improvement. It's has been used in frequent loose stools, heaviness in abdomen, gas formation, irritable bowel syndrome and also assists in digestion as soon as taken pre and postprandial. It maintains peristaltic intestinal movement and stops the movement of meal so as to undigested by loose stool [24].

According to a research, pepper corn has been used as natural remedy in appetite, dysentery, colic, piles and also assists in increasing the digestive power [21]. It has saliva stimulating and carminative properties so as to increasing the secretion of gastric juice in addition to improve appetite [25]. Based on a study, black pepper (aqueous extract) has been secondhand for the treatment of diarrhea for the reason that of antisecretary and antimotility activities with the intention of presence of carbohydrates and alkaloids active phytochemical constituents [26]. The Piper nigrum has been reported as phytochemically qualitative and quantitative at the same time as in vivo and in vitro antioxidant activity in the table 2.1, 2.2, 2.3 and 2.4 respectively.

Reseach shows that Ruta graveolens holds family of rutaceae [21]. It's indigenous to Europe [27]. It found in Middle-East, India and China mostly and their located areas are Central, South and North America. There are genera (160) and species (1600) of Ruta graveolanes. Based on a study, Rue, sudab, sadapah and fejan are the common names of Ruta graveolens [28]. It holds compounds (120) so as to containing vital oils, alkaloids, flavonoids, coumarines and furaquinolonesacridone [27]. It has Rutin with the intention of the main constituent of Ruta graveolanes that consists of flavonoids (2\%) in addition to having nitrogen oxide (NO) scavenging activity [21] It's has been used for the enema treatment when used in the decoction form that relieves the problems of colitis and flatulence. A researcher said that the paste form of sudab leaves are used for the dropsy when it practically applied on abdomen [28]. The Ruta graveolanes has been investigated as phytochemically qualitative and quantitative in the table 2.1 and 2.2 respectively.

According to a study, Carum carvi belongs to family of apiaceae [29]. It holds 3700 species and 50 general [30]. The cultivated regions of carum carvi are North America, Indonesia, China, India, Chakrata hills of Uttar Pradesh, Turkey, Siberia, Australia, Russia, Western Himalayas, Iran, Jammu and Kashmir and Egypt [31]. Carum carvi commonly called as Kala Jira. Based on a research, it consists of anethone, beta pinene, carvenone, carvacol, estragol, flavonoids, linalol, p cymene, limonene and other compounds of polyphenolic [29]. There are important secondary metabolites like as b-selinene, b-cyclolavandulal, 3-methyl ether and isoquercetrin of carum carvi. First time investigated lolavandulal and quercetin 3-methyl ether in caraway seeds; however, GC/MS also reported triacylglycerols, seed fatty acids, polysaccharides and lignin [31]. It has central and foremost constituents like 5.01\% cis-carveol, $4.67 \% \beta$ - 
myrcene, $5.21 \%$ of $\alpha$-pinene and $37.98 \%(\mathrm{R})$-carvone whereas esters and ketones, sesquiterpenes $(0.41 \%)$, saturated and unsaturated fatty acids and limonene percentage $(62.17 \%)$ are responsible for the presence of oxygenated monoterpenes and monoterpenes $(36.08 \%)$ [32,33]. It has more fruitful for human health because of the presence of mineral oils as iron, copper, selenium, calcium, magnesium, zinc, potassium and manganese whereas contains high fiber content that's why more beneficial to health and also contains vitamin C, D, E, B6 and B12 (Agrahari and Singh, 2014).

Based on a study, Carum carvi treated the digestive problems in infants and adults [34]. Carum carvi has activity in opposition to flatulence, indigestion, lack of appetite, dyspepsia in adults and colic flatulence relieving in infants, GIT spasmodic and irritable stomach problems [35]. According to a research, Caraway volatile oils have antiulcerogenic activity [36]. It has been used in anorexia, irritable syndrome and gastrointestinal (GIT) spasm [29]. It has anti diarrheal activity other than it improves bloating, flatulence, morning sickness and colic problems [20] The Carum carvi has been tested as phytochemically quantitative and in vitro antioxidant activity in the table 2.2 and 2.4 respectively.

\section{CONCLUSION}

Natural herbal plants have been used intended for the curing of stomach problems all over the world because they are more safe, effective and economical than the synthetic products. The GIT plants contain alklaloids, saponins, tannins and flavonoids that may be used for the stomach ailments for that reason that the attention of scientist is gradually more converting to ethno botanical practices for the natural plants drugs discovery in opposition to ancient and rising stomach disorders. The current synthetic products that used for the stomach ailments causing the side effects and stomach problems convert to more complication therefore; natural herbal plants are used on regular basis for the permanent eradication of stomach disorders without causing side effects.

\section{REFERENCES}

[1] Singh, R. 2015. Medicinal Plants: A Review. Journal Plant Sciences. 3 (1-1), 50-55.

[2] Edeoga, H.O., Okwu, D.E., Mbaebie, B.O. 2005. Phytochemical constituents of some Nigerian medicinal plants. African Journal Biotecnology, 4 (7), 685-688.

[3] Birben, E., Sahiner, U.M., Sackesen, C., Erzurm, S., Kalayci, O. 2012. Oxidative Stress and Antioxidant Defense. World Allergy Organization Journal, 5, 9-19.

[4] Erel, 0. 2005. A new automated colorimetric method for measuring total oxidant status. Clinical Biochemistry, 38, 1103-1111.

[5] Delfam, B., Bahmani, M., Hassanzadazar, H., Saki, K., Rafieian-Kopaei, M., Rsshidipour, M., Bagher, F., Sharifi, A. 2015. Ethnobotany study of effective medicinal plants on gastric problems in Lorestan province, West of Iran. Journal Chemical Pharmaceutical Research, 7 (2), 483-492.

[6] Ali, B.H., G. Blunden, M.O. Tanira., A. Nemmar. 2008. Some phytochemical, pharmacological and toxicological properties of ginger (Zingibe rofficinale Roscoe): A review of recent research. Food Chemical Toxicology, 46, 409-420.

[7] Gatoi, S.H., Kikuchi, A., Yi, S.S., Naing, K.W., Yamanaka, S., Watanabe J.A., Watanabe, K.N. 2006. Use of rice SSR markers as RAPD markers for genetic diversity analysis in zingiberaceae. Japan Society Breeding, 56, 107-111.

[8] Iqbal, Z., Nadeem, Q.K., Khan, M.N., Akhtar M.S., Waraich, F.N. 2001. In vitro anthelmintic activity of Allium sativum, Zingiber officinale, Curcurbita mexicana and Ficus religiosa. International Journal Agriculture Biology, 2 (4), 454-457.

[9] Aruoma, O.I., Spencer, J.P., Warren, D., Jenner, P., Butler J., Halliwell. B. 1997. Characterization of food antioxidants, illustrated using commercial garlic and ginger preparations. Food Chemistry, 60, 49-156.

[10] Mccall, M.R. Frei, B. 1999. Can antioxidant vitamins materially reduce oxidative damage in humans? Free Radical Biology Medicine, 26, 1034-1053.

[11] Miyazawa, M. Kameoka, H. 1988. Volatile flavour of Zingiberis rhizome (Zingiber officinale Roscoe). Agriculture Biological Chemistry, 52 (11), 2961-2963.
[12] Phillips, S., Hutchinson, S., Ruggier. R. 1993. Zingiber officinale does not affect gastric emptyimg rate. Anaesthesia, 48, 393-395.

[13] Backon, J. 1991. Ginger in preventing nausea and vomiting of pregnancy: a caveat due to its thromboxane synthetase activity and effect on testosterone binding. European Journal Obstetrics Gynecology Reproductive Biology, 43, 163-164.

[14] Harriot, M., Marion, E., Martha, A., Wellford, S., William, A. 2004 Inflammation induced by histamine, serotonine, bradykinin and compound 48/480 in the rat. Antagonists and mechanisms of action. Journal Pharmacology Experimental Therapeutics, 191, 300- 302.

[15] Anosike, C.A., Obidua, O., Ezeanyika, L.U.S., Nwuba, M.M. 2009. Antiinflammatory and anti-ulcerogenic activity of the ethanol extract of ginger (Zingiber officinale). African Journal Biochemistry Research, 12, 379-384.

[16] Nanjundaiah, S.M., Annaiah, H.N.M., Dharmesh, S.M. 2009 Gastroprotective effect of ginger rhizome (Zingiber officinale) extract: Role of gallic acid and cinnamic acid in $\mathrm{H}+, \mathrm{K}+/$-ATPase $\mathrm{H}$. Pylori inhibition and anti-oxidative mechanism. Evidence Based Complementary Alternative Medicine, 1-13.

[17] Chouhan, G., Islamuddin, M., Ahmad, F., Sahal, D., Arfin, F. 2014 Antileishmanial potential of Piper nigrum seed extracts against Leishmaniadonovani. Open Journal Medical Microbiology, 4, 228-235.

[18] Manoj, P., Soniya, E.V., Banerjee, N.S., Ravichandran, P. 2004. Recent studies on well-known spice, Piper longum L. Natural Product Radiance, 3 (4), 222-227.

[19] Bassey, E., Ekpo, M., Aquaisua, A., Jackson, C. 2013. Effect of Piper nigrum on salivary glands of wistar rat. Journal Medicinal Plant Research, 7 (44), 3247-3253.

[20] Gupta, P., Mahla, J., Gupta, Y.K. 2012. Antiobesity effect of safoofmohazzil, a poly herbal formulation, in cafeteria diet induced obesity in rats. Indian Journal Experimental Biology, 50, 776-784.

[21] Raghav, S.K., Gupta, B., Agarwal, C., Goswami, K., Das, H.R. 2006. Antiinflammatory effect of Ruta graveolens L., in murine macrophage cells. Journal Ethnopharmacology, 104, 234-239.

[22] Al-Mofleh, I.A., Alhaider, A.A., Mossa, J.S., M.O., Al-Sohaibani, M.O., S. Rafatullah, S, S. Qureshi. 2005. Inhibition of gastric mucosal damage by Piper nigrum pretretment in wistar albino rats. Pharmacognosy Magazine, 1, 64-68.

[23] Karsha, P.V. Lakshmi, O.B. 2010. Antibacterial activity of black pepper (Piper nigrum L.) with special reference to its mode of action on bacteria. International Journal Natural Products Resources, 1 (2), 213215.

[24] Singh, N.K., Kumar, P., Gupta, D.K., Singh, S., Singh, V.K. 2011. UVspectrometric method development for estimation of piperine in chitrakadivati. Der Pharmacia Lettre, 3 (3), 178-182.

[25] Srinivasan, K. 2005. Spices as influencers of body metabolism: an overview of three decades of research. Food Research International, 38 $77-86$.

[26] Shamkuwar, P.B., Shahi, S.R., Jadhav, S.T. 2012. Evaluation of antidiarrheal effect of black pepper (Piper nigrum L.). Asian Journal Plant Science Research, 2 (1), 48-53.

[27] Milesi, S.M.B., Gontier, E., Bourgaud, F., Guckert, A. 2001. Ruta graveolens L.: a promising species for the production of furanocoumarins. Plant Science, 161, 189-199.

[28] Parray, S.A., Bhat, J.U., Ahmad, G., Jahan, N., Sofi, G., Iqbal, S.M.F. 2012. Ruta graveolens: from traditional system of medicine to modern pharmacology: an overview. American Journal Pharmtech Research, 2 (2), 240-252.

[29] Johri, R.K. 2011. Cuminum cyminum and Carum carvi: An Update. Pharmacognosy Review, 5 (9), 63-72.

[30] Amin, M.S., Joharchi, M.R. 2016. Ethnobotanical knowledge of Apiaceae family in Iran: A review. Avecena Journal Phytomedicine, 6 (6), 621-635. 
[31] Rao, G.V., Annamalai, T., Sharlene, C., Mukhopadhyay, T., Madhavi, M.S.L. 2011. Secondary metabolites and biological studies of seeds of Carum carvi Linn. Journal Pharmaceutical Research, 4 (7), 2126-2128.

[32] Simic, A., A. Rancic, A., and M.D. Sokovic, M.D. 2008. Essential oil composition of Cymbopogon winterianus and Carum carvi and their antimicrobial activities. Pharmaceutical Biology, 46, 437-441.

[33] Meshkatalsadata, M.H., Salahvarzib, S. 2012. Identification of essential oil constituents of caraway (Carum carvi) using ultrasonic assist with headspace solid phase microextraction (UA-HS-SPME). Digest Journal Nanomaterials Biostructures, 7 (2), 637-640.

[34] Thompson, C.J., Ernst, E. 2002. Herbal medicinal products for nonulcer dyspepsia. Alimentary Pharmacology Therapeutics, 16 (10), 16891699.

[35] Al-Yahya, M., Collpharm, A. 1986. Phytochemical studies of plant used in traditional medicine in Saudi Arabia. Fitoterapia, 57, 179-82.

[36] Leporatti, M.L., Ghedir, K. 2009. Comparative analysis of medicinal plants used in traditional medicine in Italy and Tunisia. Journal Ethnobiology Ethnomedicine, 5, 31-9.
[37] Al-Sokari, S.S. Sheikha. A.F.E. 2015. In vitro antimicrobial activity of crude extracts of some medicinal plants from Al-Baha region in Saudi Arabia. Food Nutritional Sciences, 3 (1-2), 74-78.

[38] Ernest, E., Pittler, M.H. 2000. Efficacy of ginger for nausea and vomiting: A systematic review of randomised clinical trials. British Journal Anaesthesia, 84, 367-371.

[39] Ihemeje, A., Nwachukwu C.N., Ekwe, C.C. 2015. Production and quality evaluation of flavoured yoghurts using carrot, pineapple, and spiced yoghurts using ginger and pepper fruit. African Journal Food Science, 9 (3), 163-169.

[40] Kamboj, V.K. 2000. Herbal medicine. Current Science, 78 (1), 35-38.

[41] Rahmatullah, M., Das, A.K., Malik, A.H., Jhan, R., Khan, M., Rahman, T., Chowdhury, M.H. 2009. An Ethnomedicinal Survey of Dhamrai Sub-district in Dhaka District, Bangladesh. American Eurasian Journal Sustainable Agriculture, 3 (4), 881-888. 